\title{
ЛЕЗБЕЈКЕ СМО СВЕ, ЗАТО ПОНОСНЕ СМО БРЕ: БЕОГРАДСКИ ЛЕЗБЕЈСКИ МАРШ И ПОЛИТИКА ЛЕЗБЕЈСКОГ СЕПАРАТИЗМА ${ }^{2}$
}

Ancтракт: Лезбејски марш, одржан у Београду у априлу 2015. године, представља врхунац лезбејског сепаратистичког организовања које се на (пост)југословенском простору развија последњих деценија. У овом чланку се ослањам на вишеструке емпиријске изворе како бих реконструисао тај неуобичајени догађај и позиционирао га, с једне стране, у контекст (пост)југословенског феминистичког деловања и, с друге, у шире токове активистичког ангажмана инспирисане англоамеричким борбама за лезбејску (и ГБТ) еманципацију. Посвећујући пажњу контроверзама које је Марш изазвао у оквиру регионалне активистичке „заједнице”, указујем на ризике „отврдњавања” родне бинарности након пропасти југословенског социјализма.

Кључне речи: лезбејски сепаратизам, феминизам, социјализам, родна бинарност, капитализам, патријархат

\section{Увод}

После више од једне неизвесне и насилне деценије, 2015. је била annus mirabilis за активистичко организовање нехетеросексуалних и транс особа у Србији. Не само да је те године скоро неометано одржана београдска Парада поноса, већ су се на улицама српске (и бивше југословенске) престонице такође одиграли, до тада невиђени, Лезбејски марш и Транс прајд. С једне стране, изненађујућа разноликост активистичких иницијатива сведочи о способности ЛГБТ ангажмана да опстане упркос и даље распрострањеној хомо/би/трансфобији. С друге стране, пак, мноштво активистичких догађаја пажњу усмерава на сплет тензија и изазова с којима се локални активисти/киње суочавају у напору да повежу често хетерогене нити ЛГБТ еманципације.

\footnotetext{
${ }^{1}$ bojanello@gmail.com

${ }^{2}$ Уз сагласност издавача Springer Nature (№ 4930191386780) аутор је приредио незнатно измењен превод једног од поглавља монографије: Bilić, В. (2020). Trauma, Violence, and Lesbian Agency in Croatia and Serbia: Building Better Times. Palgrave Macmillan, Cham. Преведени текст су рецензирали домаћи рецензенти који су га, уз одређене сугестије, препоручили за штампу. Овде га објављујемо под ознаком „научни рад”, без квалификације „оригинални”.
} 
Београдски лезбејски марш, одржан у априлу 2015, представља врхунац лезбејског сепаратистичког организовања које се развија на (пост)југославенском простору последњих деценија. Да бих реконструисао овај активистички догађај користим различите емпиријске изворе, укључујући видео снимке, јавне изјаве, новинске чланке, online интервјуе са активисткињама/има, као и дискусију на Google групи разотквиривањез. Циљ ми је да илуструјем како је лезбејски сепаратизам, облик активистичког организовања у коме активности спроводе „жене за жене” (па, дакле, искључују мушкарце), ушао у постјугословенски простор експлицитније него икада пре, изазивајући низ контроверзи које се с овом оријентацијом повезују и у другим деловима света.

Да бих то учинио, ово јавно окупљање, прво такве врсте у региону, позиционираћу како унутар историје југословенског феминистичког/лезбејског организовања, тако и у контекст ширег англоамеричког лезбејског (и ГБТ) ангажмана. Англоамерички активизам има транснационални утицај на активистичке иницијативе, пошто се стратегије отпора углавном покрећу у Сједињеним Америчким Државама (САД) и комплексним процесима превођења (Clarke, Bainton, Lendvai, \& Stubbs 2015) укључују у логику домаћих (у овом случају полупериферних; Благојевић 2009) политичких структура.

Тврдим да је Лезбејски марш пример онога што Дела Порта (Della Porta 2018) назива „пуцањем” (cracking): нагли прекид рутине с циљем довођења у питање утврђеног поретка и остваривања јаког ефекта. У том погледу, Марш je јасан чин лезбејске видљивости, подстакнут маргинализацијом (Maljković 2016) лезбејских активисткиња, као и раширеном лезбофобијом и мизогинијом у постјугословенском друштвеном и политичком миљеу. Као протестна „пукотина", овај догађај је нагло повећао присуство лезбејки у јавном простору истичући снагу лезбејских активистичких веза унутар регионалних и европских граница. Марш је указао на постојање лезбејске „контрајавности потлачених” (subaltern counterpublic, Fraser 1990), незваничног диксурзивног поља које лезбејску сексуалност извлачи из стриктно приватне сфере и служи као платформа на којој се с идентитетима може експериментисати у јавном домену. Ширењем обима изговорљивог кроз експлицитне лезбејске пароле, активисткиње су покушале да убеде друге, па и саме себе, да „оно што у прошлости није било јавно, односно није се сматрало питањем од општег интереса, сада то треба да постане" (Fraser 1990: 71).

Међутим, остваривање лезбејског „права на град” (Bilić \& Stubbs 2015) далеко је од идеала јединства будући да је лезбејска контрајавност разнолика и подељена (Podmore 2016). Марш је открио и у извесној мери продубио раздоре међу активистичким групама и појединим активисткињама, углавном у вези с одлуком организаторки да искључе мушкарце из свог догађаја. Да бих испитао шта је омогућило ову проблематичну стратегију, Марш сам повезао с другим феминистичким и феминистичко-лезбејским иницијативама, посебно с београдским међународним скупом Друг-иза жена из 1978. године на ком се такође

\footnotetext{
${ }^{3}$ По најави Марша уследила су 52 коментара у групи.
} 
поставило питање мушког учешћа. Иако се тешко може говорити о идеолошкој хомогености у било којем од два „табора”, расцеп који се догодио крајем 70-их одразио је разлике условљене друштвеним стварностима учесница, тј. животом у (бар декларативно) социјалистичкој или капиталистичкој држави.

Растакање социјалистичких тековина и глобално слабљење државе благостања крајем 20. века отворили су простор за не увек критичку примену англосаксонских активистичких стратегија које држе регион у ,другом феминистичком таласу”, спречавајући га да се повеже с потенцијалом локалне еманципаторске баштине. Мада је замишљен као феминистичка иницијатива, Марш је повукао оштру линију међу половима, односно „потврдио” њихову наводно бинарну природу која се може сматрати структурном основом родне неравноправности. Тај догађај је, дакле, указао на контрареволуционарни карактер постјугословенске „транзиције” и на важност политике идентитета у контексту неолибералне капиталистичке доминације.

С овим на уму, у првом делу текста представићу идеолошку позадину Марша анализирајући неке од важнијих димензија лезбејског сепаратизма у САД. Потом ћу се осврнути на конференцију Друг-ца жена и потцртати један од начина на које је идеја о лезбејском сепаратизму и иницијативама намењеним искључиво женама ушла у југословенски политички простор. Такође ћу се дотаћи и других облика београдског феминистичког и феминистичко-лезбејског организовања (нпр. оснивања лезбејске активистичке групе Лабрис), како бих указао на то да је од конференције 1978. године лезбејски сепаратизам био једна од идеолошких нити којом се инспирисао лезбејски активизам у региону. Након тога дајем емпиријски приказ који укључује образложење организаторки Марша и реакције оних који/е су сматрали да би повећање лезбејске видљивости могло боље да се оствари коришћењем алтернативних активистичких стратегија. Овде ћу се ослонити на расправу покренуту најавом Марша унутар Google групе разотквиривање која окупља регионалне ЛГБТ активисте/киње. У завршном делу текста бавим се утицајима сепаратистичких активистичких стратегија на лезбејско и нехетеросексуално ослобађање уопште.

\section{Лезбејски сепаратизам}

Eнсер (Enszer 2016: 181) сматра да су „интелектуални корени лезбејског сепаратизма богати, дубоки и комплексни" иако понекад нису схваћени озбиљно чак ни у савременим феминистичким дискурсима. Лезбејски сепаратизам долази до изражаја 1970-их година, током студентских покрета широм света који су у већој или мањој мери укључивали и тзв. сексуалну револуцију, доводећи у питање традиционалне сексуалне норме. Као комбинација политичке теорије и феминистичке праксе, лезбејски сепаратизам привилегује жене и лезбејке, односно представља покушај интеракције са светом који је „учесницама обећавао живот радикалне побуне и феминистичког оснаживања” (Levy 2009: на мрежи). 
Једну од првих дефиниција лезбејског сепаратизма налазимо у изјави којом су 1970. чланице њујоршке групе Radicalesbians (1970, на мрежи) позвале жене „да у фокусу жена буду жене, и да жене стварају нову свест једна о другој и једна с другом, што је суштина женског ослобађања и основа културне револуције". Ово је 1971. подстакло Лоис Ен Едисон (Lois Anne Addison) да са својом партнерком покрене часопис Spectre у ком су се назвале „револуционарним лезбејкама” које теже „комунистичком друштву без експлоатације”. Заложиле су се за сепаратизам у кратком тексту Како прекинути дављење до смрти и дефинисале га као „рад директно и само са женама” (Enszer 2016).

Сепаратистички жар достигао је врхунац појавом радикалног лезбејског колектива од 12 жена - Фурије (The Furies Collective), које су почеле са штампањем месечника The Furies 1972. године. У свом манифесту су рекле:

Љуте смо јер нас тлачи мушка супремација. Читавог живота нас јебе систем који је заснован на доминацији мушкараца над женама, који дефинише мушкарце као добре, а жене само онолико добре колико је добар мушкарац с којим су. То је систем у којем је хетеросексуалност строго наметнута, док је лезбејска егзистенција потпуно сузбијена. Тај систем нас је поделио и по класи, раси и националности.

Овај документ указао је на најзначајнија сепаратистичка питања: истакао је лезбејство као неопходан политички избор, односно политички императив за феминисткиње, тврдећи да је тај идентитет погодан за све чланице женског покрета у друштву мушке доминације у којем је хетеросексуалност политичка институција. Манифест је такође потцртао неуспех „хетеро женског покрета” и „мушке левице” да се баве лезбејским идентитетом, инсистирајући на потреби да лезбејке саме развијају „заједничку политику лезбејске егзистенције као политичког питања". У том смислу, сепаратисткиње су лезбејски сепаратизам доживљавале не као одбацивање него као место потенцијално политички продуктивног експериментисања унутар искључиво женских заједница. Адриен Рич (Rich 1981: 88), у својству ко-уреднице другог сепаратистичког часописа Sinister Wisdom, изјавила је да:

Чин раздвајања, сепарације, такође може бити чин повезивања. Простор искључиво за жене није могуће дефинисати само као простор из кога су искључени мушкарци. То такође може бити, иако није увек, простор где жене које пре тога нису чуле једна другу могу сведочити у присуству једна друге, описати себе другим женама, стварајући тако нове нити поверења и откривајући нове могућности покрета.

Један од познатијих догађаја заснованих на лезбејској сепаратистичкој политици био је музички фестивал Мичфест (Michfest, Michigan Womyn's Music Festival) покренут 1976. године. Циљ фестивала био је да пружи простор за искључиво женско окупљање, па су све послове неопходне за његово извођење обављале жене. Иако је Мичфест био важан за многе учеснице, организација ове манифестације није прошла без контроверзи. Најпроблематичније питање, наиме, присуство транс жена (којима улаз није био дозвољен, јер је фестивал организован за „жене рођене као жене” (womyn-born womyn), уско је везано за 
лезбејски сепаратизам од његових почетака не само у САД, већ широм света (McConnell et al. 2016).

Мада су многи каснији догађаји које су организовале сепаратисткиње укључивали транс жене (као што је то био, бар декларативно, случај с београдским Маршом), лезбејски сепаратистички активизам не може се одвојити од расправа о томе како дефинисати жену. Због тога је сепаратистичка политика наишла на озбиљне критике чак и унутар феминистичких кругова већ током 70-их година. Критички тон углавном је долазио од црних феминисткиња (што не значи да није било црних сепаратисткиња), нарочито из Колектива реке Камби (Combahee River Collective), црне феминистичке лезбејске организације која је у Бостону деловала између 1974. и 1980. године. Чланице ове групе су лезбејски сепаратизам сматрале расистичком идеологијом, тврдећи у својој Декларацији да мушкарци не смеју бити искључени из прогресивних активистичких борби (Combahee River Collective 1978):

Иако смо феминисткиње и лезбејке, ми осећамо солидарност с прогресивним црнцима и не заговарамо поделу какву траже беле жене које су сепаратисткиње. Будући да смо црне, морамо да изградимо солидарност која се заснива на припадности истој раси, коју беле жене, наравно, не морају имати с белим мушкарцима, осим ако то није њихова негативна расна солидарност унутар расе која изазива опресију. Ми се заједно с црним мушкарцима боримо против расизма, док се с њима истовремено сукобљавамо због сексизма.

(...) ми одбацујемо став лезбејског сепаратизма јер за нас то није одржива политичка анализа нити стратегија. Она искључује превише питања и превише људи, посебно црних мушкараца, жена и деце. Ми критикујемо и осећамо одвратност према начину на који су мушкарци социјализовани у овом друштву: шта подржавају, како делују и како тлаче. Али немамо погрешну представу да их њихова мушкост, сама по себи, тј. њихова биолошка полна припадност, чини таквим какви су. Као црне жене сматрамо да је свака врста биолошког детерминизма изузетно опасна и реакционарна основа на којој се не може градити политика. Морамо такође пропитати да ли је лезбејски сепаратизам адекватна и прогресивна политичка анализа и стратегија, чак и за оне које га практикују, јер он негира било који извор угњетавања жена, сем рода, поништавајући тиме утицаје класе и расе.

Док су се најраније америчке лезбејске сепаратисткиње изјашњавале као комунисткиње, замишљајући заједнице само за жене, активисткиње Колектива реке Камби су се дефинисале као социјалисткиње заинтересоване за социјалистичку револуцију која би истовремено била феминистичка и антирасистичка. Јасно је, дакле, да је амерички радикални феминистички лезбејски активизам током 70-их имао леву оријентацију. То је било време у ком су предводнице женског покрета лезбејство означавале као „љубичасту пошаст” (lavender 
menace) обележивши га „контракултурном конотацијом тако снажном да је жене (лезбејству) више привлачила идеологија него жудња” (Levy 2009: на мрежи).

Штавише, лезбејски сепаратизам се појавио као одговор не само на невидљивост лезбејки у женском покрету, већ и на чињеницу да „геј” није успео да постане кровни термин за хомосексуалце, лезбејке, бисексуалне особе и остале нехетеросексуалне људе. Уместо заједничког именитеља за различите идентитете, овај термин се од 70-их година везује за мушку хомосексуалност (Trigilio 2016). Слично томе, снажна повезаност анти-AIDS активизма с мушкарцима током епидемије 80-их и појава термина квир (queer) у вези с тим, поново су пажњу одвратили од оних које/и су подвргнуте/и вишеструкој опресији, маргинализујући тако лезбејке и лезбејске заједнице.

Почетком 90-их покретом су све више доминирали бели мушкарци средње класе, а Парада поноса (Прајд) постала је институционализована, професионализована, претерано сексуализована, деполитизована и комерцијализована, што је претило да појача родне асиметрије у активистичким иницијативама (BrownSaracino \& Ghaziani 2009). Како би се супротставиле овом тренду, неколико лезбејских колектива, на челу с Лезбејским осветницама (Lesbian Avengers), групом из Њујорка основаном 1992, одлучиле су да покрену засебан лезбејски марш у склопу Марша за права и ослобађање лезбејки, гејева и бисексуалних особа у Вашингтону 1993. године. Наводно је 20 хиљада жена учествовало у овом догађају који није био први лезбејски јавни протест у Северној Америци, али је био први који је успео да иницира шири покрет (Podmore 2016). Тај марш је у наредним деценијама послужио као модел лезбејским активисткињама инспиришући слична окупљања широм Северне Америке и Западне Европе. Требало је да лезбејски маршеви буду алтернатива прајду и понуде решење за проблеме које је, по лезбејским активисткињама, он имао, дакле да створе инклузивне просторе који се опиру патријархату, капитализму, потрошачкој култури, професионализацији и деполитизацији ЛГБТ питања (Ghaziani \& Fine 2008).

\section{Конференција Друг-цฺа жена}

Трагове лезбејског сепаратизма у југословенском простору пратимо од краја 70-их година 20. века. Од 27. до 29. октобра 1978. у Београду су се (западно)европске феминистичке теоретичарке и активисткиње среле с југословенским колегиницама, махом професоркама из Загреба и Београда, на конференцији Друг-ияа жена. Женско питање: нови приступ? Овај скуп је, попут Лезбејског марша, схваћен као важан међународни догађај који треба да ојача везе међу регионалним активисткињама. Такође је означио почетак послератног аутономног југословенског социјалистичко-феминистичког покрета и улазак другог таласа феминизма у Источну Европу. Та конференција је представљала прилику да феминисткиње из два различита политичко-економска система, социјализма и капитализма, размене ставове о положају жена, тзв. „женском 
питању” у својим контекстима. По речима једног учесника (Драган Клаић, цитиран у Bonfiglioli 2008: 54):

то је био први скуп конференцијског типа посвећен феминистичким питањима, чији је циљ био повезивање људи из Београда и Загреба, других делова Југославије и иностранства. Било нас је осамдесеторо током два дана. Идеја организаторки је била да се изађе изван уског интелектуалног круга, да се укључе студенти и студенткиње и да се скрене медијска пажња. То је био догађај где је требало да мапирамо, одредимо за нас значајне теме и углавном прилика за умрежавање... и било је фасцинантно што су дошли/е сви/е из иностранства, различитих оријентација. Било је динамично, уз пуно полемика, које је, наравно, кочило превођење.

Полемичка димензија сусрета углавном се односила на чињеницу да је југословенско законодавство већ било омогућило неке од кључних еманципаторских мера којима су тежили аутономни феминистички покрети у Западној Европи. На пример, абортус је у Југославији дозвољен и регулисан од 1952 (са идејом смањења илегалних побачаја, који су у то време резултирали високом смртношћу), док је у Италији легализован у мају 1978, дакле у години конференције, захваљујући дугогодишњем ангажману феминистичких активисткиња, од којих су неке биле у Београду. Чинило се да гошће нису у довољној мери биле упознате с чињеницом да је социјалистички режим, макар декларативно и формално-правно, женску еманципацију видео као важну ставку своје политичке агенде. Већ су чланом 24 Устава Федеративне Народне Републике Југославије из 1946. године уведене законске (не нужно свуда познате и у потпуности примењене) одредбе о друштвеном статусу жена:

Жене су равноправне с мушкарцима у свим облицима државног, привредног и друштвено-политичког живота. За једнак рад жене имају право на једнаку плату као и мушкарци и уживају посебну заштиту у радном односу. Држава нарочито штити интересе матере и детета оснивањем породилишта, дечијих домова и обданишта и правом матере на плаћено отсуство пре и после порођаја (Устав ФНРЈ, на мрежи).

Услед недовољног познавања југословенског политичког контекста, учесницама из иностранства није било лако да разумеју покушај организаторки да артикулишу левичарску феминистичку критику патријархалних аспеката југословенског самоуправљања без пропитивања његових основа које су оне, у принципу, прихватале:

Ми нисмо критиковали југословенски самоуправни социјализам као такав. Критиковали смо сексистичке елементе југословенског система, с којим смо се суштински поистовећивали. У том смислу то није била радикална критика југословенског социјализма... а када погледате све те људе, они су тада били и сви су остали - не мислим да постоји иједан изузетак - против национализма (Драган Клаић, цитиран у Bonfiglioli 2008: 100). 
Напетост између гошћи и организаторки достигла је врхунац због учешћа мушкараца на конференцији, тачније, интервенције (хрватског/југословенског) социолога Слободана Дракулића који је, по речима Кристин Делфи (Christine Delphy), француске лезбејске феминистичке активисткиње и социологиње, иритирао (стране) учеснице „истинском илустрацијом мушког говора” (Delphy 1979: 131). То је подстакло једну од њих да га прекине, након чега је Дракулић замолио за стрпљење и наставио, изазвавши још јачу реакцију међународног дела публике: „Assez! Basta! Enough! На ком језику то треба рећи?” (Delphy 1979: 131). Иако се ова епизода памти на различите начине, по Лепи Млађеновић (цитирана у Bonfiglioli 2008: 92), тридесет година касније, Делфи је рекла Дракулићу да престане:

[А] за мене је прекретница била Кристин Делфи, када је једном мушкарцу рекла: „Можете изаћи, сада станите”. Било је неколико учесника који су желели да буду паметнији од нас. Био је један млади социолог левичар. Хтео је да нам објасни... говорио је, говорио, говорио, а Кристин је само рекла „знаш, требало би да станеш!”, или „чак можеш и да изађеш” ... тако нешто. Био је то огроман скандал! [смеје се] Дневни лист Политика написао је: „Феминисткиње су избациле мушкарце са конференције!”.

У осврту на конференцију, који је написала по повратку у Француску, Делфи не спомиње централну улогу коју је (наводно) имала у ућуткивању Дракулића, али каже да је „у тој збрци директорка Центра [Дуња Блажевић] узела микрофон да протестује против тако 'дискриминаторног' става, љутито додајући да „ни у ком случају нећемо правити разлику између мушкараца и жена!" (Delphy 1979: 131).

Иако не доводим у питање потребу да се прекине оно што је извесно био говор с мачистичким димензијама, желео бих да истакнем да је инсистирање организаторки на томе да не сме бити „разлике између мушкараца и жена” одразило социјалистички напор да се женско искуство посматра универзално, а не партикуларно, приступајући му као друштвеном питању од општег интереса. Овај став могао би се пратити још од укидања Антифашистичког фронта жена (АФЖ, 1953), које се понекад тумачи и као тачка прекида аутономног организовања жена у социјалистичкој Југославији. Вида Томшич (Tomšič 1980: $80)$, словеначка комунисткиња, партизанка и активисткиња, изјавила је да је до укидања Фронта дошло:

у уверењу да ће [његово] даље постојање као свеобухватне и једине женске организације, равномерно организоване одоздо према горе, [...] спречити жене да учествују у заједничким напорима за решавање друштвених проблема, подржавајући погрешну поставку да је положај жена одвојено женско питање, а не питање наше друштвене заједнице и свих бораца за социјализам...

Конференција 1978. је истакла неке од разлика у начинима на које је „женско питање” артикулисано у југословенском социјализму и западноевроп- 
ском капитализму и означила тренутак конституисања југословенског феминистичког покрета после Другог светског рата. Скуп је подстакао низ мање или више формалних иницијатива у Србији и Хрватској (на пример, група Жена и друштво, прво у Загребу, а потом у Београду), али је такође постао и једна могућа иницијална тачка српског/југословенског лезбејског организовања. Сусрет с Кристин Делфи трансформативно је утицао на Лепу Млађеновић која је у то време имала 24 године. Млађеновић (цитирана у Bonfiglioli 2008: 91) о том моменту каже:

Покушавала сам да је разумем. Била је потпуно другачија [...] одакле та жена, из ког света? Нисам баш била свесна ... нешто ме је привлачило ... није била нечија супруга. Ходала је улицама не обазирући се на мушке очи. То је била разлика коју сам тек касније формулисала.

Разлика коју је Лепа Млађеновић приметила била је нарочито видљива у ресторанима у којима ће се учеснице окупљати након формалних делова конференције.

Да сам могла да бирам на кога бих желела да личим, изабрала бих њу. Не због онога што је причала о теорији. Лакоћа с којом је ходала мушким светом; аутономно, самодовољно, у простору није зависила од хетеросексуалне валидације, а сваки простор је простор мизогиније. Осећала сам да она осећа да је сваки простор њен простор. То сам разумела као енергију... није очекивала од конобара одобравање, нити је уопште намеравала да објашњава свим тим мушкарцима ко смо ми. Обично су жене око мене покушале да се оправдају или су флертовале... она није трошила енергију на то (...) јер то је твој свет, иако знаш да није. У том је смислу била јако важан модел. Била је јако паметна и већ је интернализовала феминистичке принципе и то је оно што сам осећала, како стварно живиш феминизам. То је тотално променило начин на који сам себе схватала и како сам видела оно што могу да урадим једног дана. Ако хоћу да се бавим истраживањем, могу да истражујем жене, о томе нисам никад раније мислила. А историја југословенског организовања је заправо почела тим догађајем (Млађеновић цитирана у Bonfiglioli 2008: 93).

Ефекти ове конференције видели су се у наредним деценијама у којима је Лепа Млађеновић постала препознатљиво лице (пост)југословенског феминистичког лезбејског активизма. Истинска регионална активисткиња која својим деловањем покрива територију бивше државе и ствара везе са женама из других делова Европе и САД-а, Млађеновић деценијама оснажује жене, промовишући политику женског и лезбејског сепаратизма. Млађеновић је 1986. заговарала активности само за жене у оквиру београдске групе Жена и друштво (Lóránd 2018), 1993. је била једна од оснивачица Аутономног женског центра, а 1995. је била кључна за оснивање прве лезбејке организације Лабрис, настале одвајањем од прве српске нехетеросексуалне активистичке групе Аркадија. Такође, подржала је многе лезбејске активистичке иницијативе које су започињале широм региона. Као што пише активисткиња из Северне Македоније Ирена Цветковик (Cvetkovik 2019: 142): 
Лезбејска група коју је Гордана водила у оквиру МАССО организовала је радионице и догађаје на разне теме, углавном заједно са активисткињама из Србије и бивше Југославије, као што је Лепа Млађеновић. Лепа је често долазила у Скопље да подржи македонске сестре и инсистирала је да лезбејке треба да се одвоје од других ГБТ група. Мотивисана овим састанцима, Гордана је, заједно с неколико жена, основала Женску алијансу, прву лезбејску организацију у Македонији.

У овом смислу, активистички ангажман Лепе Млађеновић омогућује да се прати једна нит женског/лезбејског сепаратизма кроз различите епизоде у (пост)југословенској феминистичкој историји.

\section{Београдски лезбејски марш}

Београдски лезбејски марш одржан је у оквиру Лезбејског пролећа, четвородневног догађаја који је у априлу 2015. организовала група активисткиња из Србије и Босне и Херцеговине. На њему су се окупиле лезбејке из постјугословенског региона и активисткиње повезане с Феминистичким караваном (Caravana feminista) који је од марта до октобра 2015. путовао Европом (са задржавањима у Београду и Загребу), с циљем да документује женску борбу за једнакост. Програм Лезбејског пролећа чиниле су радионице и панели, а догађај је окончао Лезбејски марш. Активисткиња Зое Гудовић истакла је да је један од главних циљева Марша било скретање пажње јавности на дискриминацију коју трпе жене и лезбејке. О томе је рекла:

Изласком на улицу показујемо да нисмо увезене са Запада, ми постојимо у овој земљи, ми смо грађанке овог друштва и ми градимо ово друштво и трудимо се да се навикне на промене. Промене су ту када људи схвате колико је политичка опресија везана за жене, а онда тек за лезбејке у ствари свеприсутна. Данас смо искорачиле из тога и рекле да нећемо да будемо у систему који нас тлачи, а тиме, свесне смо, постајемо и претња. Овим данас и целим програмом (Лезбејског пролећа) показале смо нашу снагу и чињеницу да смо потпуно способне и спремне да мењамо друштвене околности. То, наравно, није лако, али пут је тек пред нама (Телеграф 2015: на мрежи).

Марш је такође схваћен и као прилика за другачији облик активизма који садржи имплицитну критику српских/регионалних геј и левих иницијатива, које су организаторке виделе као превише патријархалне и мушкоцентричне. Једна од њих, Ана Пандеј, каже:

Лезбејски марш представља врхунац програма Лезбејског пролећа које смо организовале јер сматрамо да су лезбејке генерално вишеструко невидљиве у друштву. Ми смо ту, на протестима, а нема нас. На радничким протестима, на женским протестима, на Прајду... Нигде нема лезбејки и увек је нека друга сцена у првом плану. Изузетно је важно да жене генерално, првенствено лезбејке, а онда и све другарице које су хетеросексуалне, бисексуалне, квир, заузму јавни простор саме (Телеграф 2015: на мрежи). 
У том смислу, у једној од најава Марша истиче се волонтерска природа ангажовања организаторки. Тиме је овај догађај представљен као противтежа углавном професионализованом облику активизма у региону, који је довео до израженог удаљавања активиста/киња од њихових заједница (Butterfield 2016). Организаторке (Лабрис 2015: на мрежи) су навеле:

Ми смо група grassroots лезбејки, пријатељица, активисткиња из различитих група из Србије и БиХ и желимо да овог априла Лезбејско пролеће заиста процвета! Наш рад је заснован на феминистичким и волонтерским принципима. Желимо да станемо на пут патријархату и лезбофобији и да обележимо 25 година постојања лезбејског покрета у Србији! Све смо свесне да су друштвене околности у Србији веома негативне када је реч о лезбејкама - суочавамо се са константном лезбофобијом, напади на лезбејке су учестали, и потенцијално је опасно држати се за руке на јавним местима или испољавати блискост.

Марш је одржан 19. априла и започео је у Пионирском парку, прошао улицама Краља Милана и Ресавском да би завршио у Центру за културну деконтаминацију, кључном месту београдске алтернативне „сцене”, блиско повезаном са антиратним иницијативама српских интелектуалаца (Београдски круг). Видео запис о Маршу, који је направила Мириам Фужер (Myriam Fougère), ${ }^{4}$ показује групу жена предвођену Зое Гудовић, које певају: „Лезбејке смо све зато поносне смо бре!". Овај слоган је био централни део дужег перформанса који је укључивао и следеће стихове:

\section{Стално нам говоре}

ово нису ваше улице.

Стално нам говоре

да идемо међу наше сигурне зидове.

Стално нам говоре

не ви и ваше прљаве оргије.

Стално нам говоре

ово нису ваше улице.

Е па чуј нас, ја ти кажем на сав глас, отвориле смо ормаре!

Стихови песме Зое Гудовић обележили су једну од најважнијих тачака Марша, када су учеснице, узевши у обзир лезбофобију свог друштвеног окружења претвориле догађај у тренутак оснаживања кроз колективни coming out. Овај чин представљао је експлицитни израз лезбејске видљивости јер је „излазак из ормара” изведен на јасно артикулисан и чак бунтовнички начин („слушај, данас ћу то рећи гласно”) излажући београдске улице и српску/регионалну јавну сферу до тада невиђеном лезбејском присуству.

Међу најистакнутијим транспарентима био је Лезбијке уз лезбејке - Хр

\footnotetext{
${ }^{4}$ Видео је доступан на адреси: www.youtube.com/watch?v=QFJD3DwdP3c
} 
$C p$ који је лезбејски активизам учинио и антинационалистичким, истакавши везу међу активисткињама из Србије и Хрватске. Овај транспарент указао је на вишедеценијску отпорност српско-хрватских феминистичких веза потцртавајући способност феминизма да заобиђе етнички хомогенизујуће режиме и сачува регион као простор заједничке политичке борбе. Марш није имао само регионални, већ и шири, транснационални карактер, јер су се скандирале пароле и транспаренти писани на више језика (између осталог на арапском, албанском, француском, шпанском), наглашавајући потребу за међународном женском/лезбејском солидарношћу.

Међутим, паралелно са позитивним аспектима, организацију Марша су од почетка пратиле тензије. У првој најави послатој у групу разотквиривање у циљу подстицања учешћа писало је да је „марш лезбејски и самим тим намењен само женама. Марш слави лезбејски покрет у Србији и промовише феминистичку политику". Овај део позива покренуо је дебату међу члановима/ цама групе и подстакао геј активисту Душана Маљковића (разотквиривање, април 2015) да каже:

Заиста је невероватно да 2015. неко организује политички протест и да онда из њега искључи један пол. Мој први утисак је био изненађење и неверица. Зашто, забога? Покушао сам да пронађем одговор у једној јединој реченици која се нуди у позиву: „С обзиром на то да је лезбејски марш, намењен је само женама”. Таква аргументација (која суштински изостаје) наводно је саморазумљива но суштински контрадикторна - зашто се, ако се инсистира на томе да је у питању ЛЕЗБЕЈСКИ марш, позив упућује СВИМ женама, дакле и нелезбејкама? Разумео бих да је у питању или приватан догађај, или некаква нпр. психолошка радионица у оквиру неког јавног дешавања, али да се у јавном простору некоме напомиње да не долази по полној основи мени је заиста скандалозно репресивно. Да не напомињем колико је све политички контрапродуктивно јер се тако искључују мушки подржаваоци лезбејског покрета којих има и у које и себе убрајам.

Одлука организаторки да искључе мушкарце била је занимљива и у светлу чињенице да су демонстранткиње морале да уђу у кордон полицајаца који се с њима кретао дуж читаве маршруте. У позиву је наведено да су организаторке пријавиле Марш полицији, али да нису обавестиле медије о томе. Ово је стратегија коју ЛГБТ активисти/киње понекад користе како би смањили вероватноћу насиља, јер члановима десничарских група не дају довољно времена да организују потенцијално агресиван одговор. Кордон полиције (који се виђа, нпр. приликом протеста Жена у ирном) одваја активисте од јавности и иако доноси сигурност, наглашава напетост између учесника протеста и његових посматрача стварајући „активистичку енклаву” која истовремено потврђује и угрожава ,јавност” јавног простора.

Иако је Марш, први такве врсте, имао велики симболички значај, његово извођење, обележено јаким полицијским присуством, ограничило је и његов капацитет да превазиђе фазу инцидента или нехетеронормативног тренутака који би се могао проширити на оне које/и нису биле/и изричито позване/и или лично заинтересоване/и за лезбејску ствар. Ненајављивање протеста и 
умањење његове јавне димензије је разумљива одлука са становишта избегавања насиља, али је спроведена у дело по високој цени, јер је Марш ограничила на уске кругове организаторки, истичући углавном урбани карактер активизма у Србији и региону. Један од критичара Марша у дискусији на групи разотквиривање (април 2015) рекао је:

...ко на те маршеве посебно овде и на параде иде а ко није у веома привилегованој позицији?!! Иду бре људи који живе $100 \mathrm{~m}$ од тог парка који имају све повластице. Па 99\% мушкараца је у овој земљи више дискриминисано и у далеко јаднијем положају него било која сепаратисткиња која учествује на том маршу или на тзв. паради тзв. поноса.

Већина лезбејских (и геј) активистичких иницијатива у Србији израсла је из антиратног организовања 90-их година које је мобилисало „најгласнији део широко распрострањеног, југословенског, урбаног, космополитског и истински не-етно-националистички настројеног културног идентитета" (Dević 1997: 156). Тада се грађански активизам појавио и као стратегија опстанка урбане средње класе која је нестајала под теретом сиромаштва и међународне изолације (Bilić 2015). Многи активисти/киње су прошли процес професионализације односно замене спонтаних иницијатива „пројектима” чија се имплементација састојала, између осталог, од управљања буџетима и писања извештаја. Тако нагло сужавање активистичког поља и дан-данас представља извор напетости и фрустрације (Bilić 2015).

Иако су организаторке Марша истакле да су „независне” и да су радиле добровољно, листа организација које су подржале догађај показује да су оне на један или други начин повезане с београдским невладиним организацијама за људска права. Подела рада и такмичење за све оскудније ресурсе створили су међуорганизационе расцепе који доводе до дуплирања иницијатива и поновљених „иницијалних” догађаја у којима су урбане средине привилеговане. ${ }^{5}$ У овом смислу, Куртовић (Kurtović 2012: 220) пише да је у опкољеном Сарајеву урбаност била синоним за хуманистичке и космополитске идеале неповерљиве према институционалној политици, односно за инсистирање на креативном изражавању као супротности ,патриотизму, националном поносу и традицији”. „Урбоцентрична ексклузивност” (Jansen 2005: 267) довела је до тога да важност урбаног хабитуса на простору бивше Југославије често надилази националну припадност, чинећи да се људи који га присвајају у различитим државама осећају ближе једни другима него својим „мање урбаним”/руралним сународницима/цама. Иако су жене из мањих српских градова учествовале у активностима Лезбејског пролећа, изгледа да више од три деценије феминистичког ангажмана у Србији још увек није дестабилизовало перцепцију да

\footnotetext{
${ }^{5}$ У дебати поводом Марша, геј активиста Предраг Аздејковић (разотквиривање, 15. април 2015, на мрежи) рекао је: „То је генерална бољка српског ЛГБТ покрета, да воли да ставља редни број 1 испред многих ствари... Тако да смо прошле године имали три прве регионалне ЛГБТ конференције!”.
} 
су еманципаторске борбе урбани феномен резервисан за жене средње класе. ${ }^{6}$ Тако Савић (Savić 2017: на мрежи), пишући о Маршу жена против фашизма 2017. године, који назива и „ријалити шоу солидарности“ (а који се одржао у Београду, започео у Пионирском парку и вероватно окупио многе активисткиње које су биле и учеснице Лезбејског марша), каже:

Бавити се феминизмом у Србији је класна привилегија белих, образованих жена, углавном из Београда. Тешко ако сте сиромашни или радите у НЦР-у (National Cash Register ${ }^{7}$ ), што је још привилегија - [...] У тој експлоататорској фирми [...] ви радите лудачке ноћне и дневне смене које трају цео дан, и немате снаге да погледате било каква куцана слова на папиру од целодневног буљења у екран, а камоли да отворите компјутер и да се информишете шта се уопште дешава око вас [...]. Феминизам није показао неко посебно интересовање да у своје редове укључи жене које раде у НЦР-у, а камоли неке друге, мање „срећне” жене. Он не нуди никакво посебно решење за жене у НЦР-у. [Те жене] не интресују исто тако академски леви феминизми белих жена. Шта је Алтисер рекао њима би можда могло да буде од користи, али оне за то немају снаге, ни времена да читају, да уче. Немате ви привилегију да се образујете кад сте сиромашни и кад морате да радите било шта.

Комбинација урбаног елитизма и антинационализма, у оквиру полицијско-активистичке „енклаве”, јача перцепцију активиста/киња о посебности и различитости од шире јавности којој се обраћају с циљем да донесу друштвене промене. Активисти/киње у ствари делују на размеђу међународног и локалног ангажмана (intermestic actors) „преводећи” вредности западне модерности у локални контекст и репродукујући пратеће хијерархије моћи (Bilić 2015; Bilić $\&$ Stubbs 2015). Због тога су се у online дебати неки учесници/це запитали зашто су о Маршу обавештени као о „свршеној ствари” уместо позива на расправу о томе како га организовати. Као што је једна активисткиња изјавила (разотквиривање, април 2015):

У ЛГБТ активизму, па и лезбејском, упорно се пада на испиту феминизма и демократског одлучивања. Није ствар у томе да ви мене као лезбејку боље информишете top-down да ће догађај да буде women-only (не чак ни lesbian-only) него да нас питате да ли се ми сви (већински) у заједници о којој се ради слажемо с политикама које се спроводе у наше име. Овде се ипак ради о јавном политичком догађају, а не о приватној журци или секс клубу (где могу да постоје приватна правила и политике у оквиру закона, с којима можемо и не морамо да се слажемо). Што се повређених осећања посетилаца/тељки тиче (то не морају бити нужно активисти/киње) нас најмање 100 (онолико колико сигурно знам) није дошло због овакве политике и начина њеног спровођења.

Овај део расправе наглашава потешкоће концептуализације и практиковања демократске префигуративне политике у ауторитарним и сиромашним

\footnotetext{
${ }^{6}$ Феминистичка регионална мрежа Жене у црном је посвећена проблематизацији урбаноруралних разлика у Србији и региону. Има све више феминистичких иницијатива које напуштају оквире главног града.
}

${ }^{7}$ Америчка компанија која запошљава неколико хиљада људи у Србији. 
срединама. Лидерски стил власти често се одражава и прелама и у активистичким круговима, што резултира недостатком смисленог дијалога и лаким одбацивањем алтернативних мишљења (Bilić 2015; Kučinac \& Hrga 2021).

Штавише, Марш је есенцијализацијом родне бинарности у јавном простору разоткрио парадокс који прати радикални феминистички лезбејски сепаратизам. Организовани лезбејски маршеви, попут београдског, „само за жене”, не могу избећи изазов (бар имплицитне) дефиниције жене. Док се с једне стране радикални феминизам бори против „патријархалних” наметања норми о томе како би жене требало да изгледају, с друге стране ризикује да се сведе на стереотипне дефиниције женскости. Како је Маљковић (разотквиривање, 2015) приметио:

Лезбејски марш је ексклузивна манифестација која заправо само на неколико сати у ограниченом простору демонстрира традиционално патријархалну димензију моћи а то је полно искључење (само „обрћући” пол који је искључен, не мењајући ништа на форми моћи која се демонстрира) и претвара јавни простор у приватни, док инклузивна манифестација управо деконструише патријархалну димензију моћи и отвара простор за изградњу политичке једнакости, потврђујући јавном простору његову универзалност и демократичност.

Када се и ови аспекти узму у обзир, Марш се може оценити као иницијатива која је изазвала поделу и одвратила многе (жене) од учешћа. Лепа Млађеновић (разотквиривање, 2015) након догађаја је изјавила:

У конкрентом случају изостала је дискусија у широј заједници, изостало је пуно обавештења и појашњења од стране организаторки, изостало је договарање и преговарање. [...] схватила сам да је било јако много пропуста од организаторки тако да је пуно повређених активисткиња и активиста на све стране, и јако ми је жао због тога. Исто тако чујем и знам да има велики део заједнице који се не слаже с концептом Лезбејског марша.

\section{Закључак}

Међународни лезбејски марш у Београду био је одлучна манифестација лезбејске видљивости. Кроз колективни coming out, овај догађај је указао на крхкост еманципаторских достигнућа у време јачања популизма и истакао жилавост патријархата не само у општој популацији, него и у активистичким подухватима који стреме (нехетеро)сексуалном ослобођењу. Марш се појавио као двоструки симптом (ре)патријархализације: његов идеолошки садржај осветлио је маргинализацију женских и лезбејских права, док је његова форма заснована на родној бинарности преокренула смер родног искључивања. Иако су овога пута жене искључиле мушкарце из јавног простора, тиме нису дестабилизоване, већ само репродуковане патријархалне матрице друштвеног организовања. 
Искључујући мушкарце из свог окупљања, организаторке Марша нарушиле су јавну природу јавног простора и ослабиле критичку функцију контрајавности потлачених (Fraser 1990). Иако није немогуће да заврши у изолацији, активистичка група која полаже право на јавни простор не може саму себе изоловати, односно учинити се „енклавом”. Другим речима, контрајавност у принципу има тенденцију противљења сепаратизму јер преузима јавну оријентацију која јој омогућава да се конституише као део јавности и ступи у отворену интеракцију с другим актерима у јавној арени. Колико год били подређени, чланови/це контрајавности себе доживљавају као део потенцијално шире јавности којој се обраћају и на коју желе да утичу.

Неуобичајено оштра стратегија искључивања довела је до тога да организаторке Марша наиђу на парадокс који срећемо и код других лезбејских сепаратистичких организација: иако декларативно прихватају идеју укључивања, организаторке су Марш искористиле као средство потврђивања ужег идентитета који не деле све (нехетеросексуалне) жене или други подржаваоци права нехетеросексуалних особа. Мада су савремени лезбејски маршеви махом јавни догађаји с дугом традицијом, који су транс-инклузивни (нпр. Лезбејски марш за љубав у Лос Анђелесу), они маршеви који искључују „други род” или групе људи чији родови надилазе традиционалну родну поделу, у пракси доприносе одржавању родно-бинарног система који је у сржи родно заснованог насиља.

Свака активистичка иницијатива базирана на идентитету наилази на оно што je Гамсон (Gamson 1995) назвао „квир дилемом”: фиксне идентитетске категорије истовремено су основа за угњетавање и платформа на којој се стиче политичка моћ. Док подривање одређених идентитета може продубити дискриминацију и бити политички штетно, есенцијализам у њиховом разумевању доприноси опстанку структурних услова који такву дискриминацију чине могућом. То што су неке организаторке Лезбејског марша (попут Зое Гудовић) (биле) укључене у експериментисање с појмом квира (нарочито у оквиру Београдског квир колектива, Bilić \& Dioli 2016), показује да квир, који истиче флуидност идентитета проблематизујући одрживост сексуалних или родних категорија, можда није испунио своје политичко обећање: наиме, оставио је простор за уплив есенцијалистичких приступа који коегзистирају и/или се надмећу са онима који су више деесенцијализирајући. Стога ваља увек изнова поставити питање о томе како идентитете привремено и стратешки стабилизовати на начин који би осигурао да се неће пренебрегнути (интерсекционална) идентитетска укрштања или угрозити права других.

Иако такав приступ захтева много дугорочног политичког рада, јасно је да се радикална решења „квир дилеме” која би подразумевала искључивање из јавног простора не могу трансформисати у одрживе политичке промене. Кроз стратешки избор који промовише родну бинарност, активистичка „енклава” ограничена је не само физички, полицијским кордоном, већ и идентетски. На исти начин на који физичка „енклава” разоткрива напетост између учесника/ ца и посматрачке јавности, идентитетска формира простор разграничења који се нужно (и често конфликтно) урушава, јер никада није довољно широк да укључи све облике женског, односно људског искуства. 
Имајући то у виду, Марш је пружио илустрацију процеса кроз који се феминистичко знање губи у периоду после југословенског социјализма. У овом раду сам се вратио на конференцију из 1978, као једну од кључних тачака феминистичког организовања на југословенском простору, како бих показао да прогресивно наслеђе социјалистичког режима, који су учеснице југословенске конференције истовремено критиковале и признавале, није призвано као могућа противтежа одлуци организаторки Марша да спрече мушкарце да учествују у јавном догађају. Активисткиње се нису у довољној мери ослониле на своје социјалистичке претходнице, па нису довеле у питање такву стратешку опцију са становишта универзалних људских борби.

Ово је отворило пут Маршу не само да заоштри родну бинарност која представља структурно језгро родне дискриминације већ и да постане израз политике идентитета уско повезане с неолибералном капиталистичком доминацијом. Док је социјализам настојао да уставно изједначи политички, социјални и економски статус мушкараца и жена (што је дестабилизовало, али није искоренило патријархат), родна бинарност је једно од основних својстава модерног капитализма, пресудно за начин на који се у њему организује подела рада. Из тог разлога су капиталистичка експанзија и брза репатријархализација ишле „руку под руку” након пада социјализма: капитализам тежи смањењу трошкова рада систематском репродукцијом патријархата и деградирањем права жена које држи у положају зависности од мушкараца, пружајући само некима од њих привилегију уживања у либералном поретку (Jandrić 2018).

Међутим, теоријски вакуум настао распадом Југославије и слабљењем њених (социјалистичких) феминистичких традиција не би се могао тако брзо попунити знањем и активистичким стратегијама западних друштава напредног капитализма (нпр. Поворке поноса, Лезбејски марш, итд.) да није било израженог проблема с патријархатом и у капиталистичким и у социјалистичким системима. (Пост)југословенску регију није тек случајно „захватила” сепаратистичка (лезбејска) идеологија развијена у САД током седамдесетих година - такав аргумент би оспорио моћ локалних актерки да интервенишу у сопственом јавном простору.

Уместо тога, сепаратистичке идеолошке опције рачунају на локалну активистичку струју која се из отпора према патријархату појавила већ у социјалистичком контексту. Након пропасти социјализма, стекли су се услови за то да се она разбукта с радикалношћу коју је у међувремену углавном изгубила у местима свог порекла: интензивирање транс активизма оголило је њене искључујуће димензије (Bakić 2020; Kučinac \& Hrga 2021), позивајући (нас) још једном на (утопијски) пут прогресивних политика окупљања свих који/е су посвећени/е родној и сексуалној еманципацији. У том смислу, Београдски лезбејски марш није само ,једнократна” манифестација коју је група „независних активисткиња” организовала „на брзину”. Напротив, тај догађај је осветлио вишедеценијску путању дела (пост)југословенског феминистичког ангажмана чији су резултати оснаживања и слободе окрњени нелагодом поделе и дискриминације. 


\section{Литература}

Bakić, A. (2020). TERF: Radikalna desnica u feminističkom ruhu. https://voxfeminae.net/ pravednost/terf-radikalna-desnica-u-feministickom-ruhu/

Bilić, B. (2015). Borile smo se za vazduh: (Post)jugoslovenski antiratni aktivizam i njegovo nasleđe. Zagreb: Documenta, Kuća ljudskih prava i Jesenski i Turk.

Bilić, B., \& Dioli, I. (2016). "Queer Beograd Collective: Beyond single-issue activism in Serbia and the post-Yugoslav Space”. U Intersectionality and LGBT Activist Politics: Multiple Others in Serbia and Croatia, uredili Bojan Bilić i Sanja Kajinić, 105-125. London: Palgrave Macmillan.

Bilić, B. \& Stubbs, P. (2015). "Unsettling "the Urban" in Post-Yugoslav Activisms: Right to the City and Pride Parades in Serbia and Croatia". U Urban Movements and Grassroots Activism in Central and Eastern Europe, uredila Kirsten Jacobsson, 119-138. London: Ashgate.

Blagojević, M. (2009). Knowledge Production at the Semiperiphery: A Gender Perspective. Beograd: Institut za kriminološka i sociološka istraživanja.

Bonfiglioli, Ch. (2008). "Belgrade 1978 Remembering the Conference "Drugarica zena. Žensko pitanje - novi pristup?" “Comrade Woman. The Women's Question: A New Approach?” thirty years after. Master teza. Univerzitet u Utrehtu.

Brown-Saracino, J. \& Ghaziani, A. (2009). "The Constraints of Culture: Evidence from the Chicago Dyke March." Cultural Sociology 3 (1): 51-75. https://doi. org/10.1177/1749975508100671

Butterfield, N. (2016). "Discontents of Professionalisation: Sexual Politics and Activism in Croatia in the Context of EU accession." U LGBT Activism and Europeanisation in the Post-Yugoslav space: On the Rainbow Way to Europe, uredio Bojan Bilić, 23-58. London: Palgrave Macmillan.

Clarke, J., Bainton, D., Lendvai, N. \& Stubbs, P. (2015). Making Policy Move: Towards a Politics of Translation and Assemblage. Bristol: Policy Press.

Combahee River Collective. (1978). “A Black Feminist Statement.” Pristupljeno 24. avgusta 2020. https://americanstudies.yale.edu

Cvetkovik, I. (2019. "Probijanje tišine: Lezbejski aktivizam u Makedoniji”. U Sestrinstvo i jedinstvo: Lezbe/ijski aktivizam u (post)jugoslo/avenskom prostoru, uredili Bojan Bilić i Marija Radoman, 126-148. Novi Sad: Mediterran Publishing.

Della Porta, D. (2018). "Protests as Critical Junctures: Some Reflections towards a Momentous Approach to Social Movements." Social Movement Studies 11 (3-4): 1-20. https://doi.org/10.1080/14742837.2018.1555458

Delphy, Ch. (1979). "Novelles de Yougoslavie: Lueurs féministe en pays socialistes Belgrade 1978." Questions féministes 5: 129-136.

Dević, A. (1997) “Anti-War Initiatives and the Un-Making of Civic Identities in the Former Yugoslav Republics.” Journal of Historical Sociology 10 (2): 127-156. https://doi. org/10.1111/1467-6443.00034

Enszer, J. R. (2016). “'How to Stop Choking to Death': Rethinking Lesbian Separatism as a Vibrant Political Theory and Feminist Practice." Journal of Lesbian Studies 20 (2): 180-196. https://doi.org/10.1080/10894160.2015.1083815 
Fraser, N. (1990). "Rethinking the Public Sphere: A Contribution to the Critique of Actually Existing Democracy." Social Text 25/26: 56-80. https://doi.org/10.2307/466240

Gamson, J. (1995). "Must Identity Movements Self-Destruct? A Queer Dilemma. Social Problems 42 (3): 390-407. https://doi.org/10.2307/3096854

Ghaziani, A. \& Fine, G. A. (2008). "Infighting and Ideology: How Conflict Informs the Local Culture of the Chicago Dyke March.” International Journal of Politics, Culture and Society 20 (1-4): 51-67. http://dx.doi.org/10.1007/s10767-008-9032-x

Jandrić, I. (2018). “Institucionalni patrijarhat kao zakonitost kapitalizma.” Pristupljeno 20. avgusta 2020. http://slobodnifilozofski.com/2018/12/institucionalni-patrijarhat-zakonitost.html

Jansen, S. (2005). Antinacionalizam: Etnografija otpora u Beogradu i Zagrebu. Beograd: $\mathrm{XX}$ vek.

Kurtović, L. (2012). “The Paradoxes of Wartime 'Freedom': Alternative Culture during the Siege of Sarajevo." U Resisting the Evil: Post-Yugoslav Anti-War Contention, uredili Bojan Bilić i Vesna Janković, 197-224. Baden-Baden: Nomos

Kučinac, D., \& Hrga, K. (2021). Karolina Hrga: Balast prividnog konsenzusa u feminizmu. https://www.bilten.org/?p=35715

Labris. (2015). "Najava: Lezbejsko proleće u Beogradu od 16. do 19. Aprila”. Pristupljeno 20. avgusta 2020. http://arhiv2015sr.labris.org.rs/najava-lezbejsko-prolece-ubeogradu-od-16-do-19-aprila/

Levy, A. (2009). "Lesbian Nation: When Gay Women Took to the Road." The New Yorker. Pristupljeno 20. avgusta 2020. www.newyorker.com/magazine/2009/03/02/ lesbian-nation

Lóránd, Zs. (2018). The Feminist Challenge to the Socialist State in Yugoslavia. London: Palgrave Macmillan.

Maljković, D. (2016). "Queer Struggles and the Left in Serbia and Croatia: An Afterword." U Intersectionality and LGBT Activist Politics: Multiple Others in Croatia and Serbia, uredili Bojan Bilić i Sanja Kajinić, 213-224. London: Palgrave Macmillan.

McConnell, E. A. et al. (2016). "Trans Women and Michfest: An Ethnophenomenology of Attendees' Experiences.” Journal of Lesbian Studies 20 (1): 8-28. https://doi.org/10 $.1080 / 10894160.2015 .1076234$

Podmore, J. (2016). “Contested Dyke Rights to the City: Montréal's 2012 Dyke Marches in Time and Space." U Lesbian Geographies: Gender, Place and Power, uredile Kath Browne i Eduarda Fereira, 71-89. London: Routledge.

Radicalesbians. (1970). “The Woman Identified Woman.” Pristupljeno 20. avgusta 2020. https://dukelibraries.contentdm.oclc.org/

Rich, A. (1981). “Notes for a Magazine: What Does Separatism Mean?" Sinister Wisdom 18: 83-91.

Savić, J. (2017). “Ženski marš iliti rijaliti šou solidarnosti.” Pristupljeno 20. avgusta 2020. http://proletter.me/portfolio/zenski-mars-iliti-rijaliti-sou-solidarnosti/

Telegraf. (2015). “Lezbejsko proleće: Održan prvi ženski gej marš u Beogradu, da li je protekao bez incidenata?" Pristupljeno 20. avgusta 2020. http://www.telegraf.rs/ vesti/beograd/1531608-lezbejsko-prolece-odrzan-prvi-zenski-gej-mars-u-beograduda-li-je-protekao-bez-incidenata 
Tomšič, V. (1980). Woman in the Development of Socialist Self-Managing Yugoslavia, Beograd: Jugoslovenska stvarnost.

Trigilio, J. (2016). "Complicated and Messy Politics of Inclusion: Michfest and the Boston Dyke March.” Journal of Lesbian Studies 20 (2): 234-250. https://doi.org/10.1080/1 0894160.2016.1083835

Ustav FNRJ. (1946). Pristupljeno 20. avgusta 2020. http://mojustav.rs/wp-content/ uploads/2013/04/Ustav1946.pdf

Bojan Bilić

\title{
WE ARE ALL LESBIANS AND PROUD OF IT: BELGRADE LESBIAN MARCH AND THE POLITICS OF LESBIAN SEPARATISM
}

\begin{abstract}
The 2015 Belgrade Lesbian March represented the culmination point of the fragile but resilient lesbian separatist thread that has been developing in the (post-)Yugoslav space over the last decades. In this paper I draw upon a variety of empirical sources to reconstruct that gathering and contextualise it both in the history of Yugoslav feminist/lesbian organising as well as in the broader, Anglo-American history of lesbian (and GBT) activist mobilisations. I use the controversies that the March provoked within the activist 'community' to engage with the broader issues around reifications of the gender binary in the wake of Yugoslav socialism.
\end{abstract}

Keywords: lesbian separatism, feminism, socialism, gender binary, capitalism, patriarchy 